\title{
Effects of Globalisation on the English Language
}

\author{
Sadiya Jalal \\ Research Scholar \\ Department of English \\ Aligarh Muslim University \\ Aligarh, Uttar Pradesh, India \\ sadiya.jala193@gmail.com
}

\begin{abstract}
Scholars, academicians, economists have given different definitions of globalisation, highlighting mostly the economic and political consequences of globalisation. However, this paper aims at shifting the attention from the much talked economic and political consequences of globalisation to its effects on the English language concerning the Indian context. In other words, this paper aims to trace the various effects of globalisation on the English language. After going through relevant literature survey, the researcher has come up with the answer that globalisation has resulted into the further spread of the English language by changing its role in the global affairs, has given birth to indigenous varieties of English and to a new medium of communication which is neither speech nor writing but shares some of the characteristics of both.
\end{abstract}

Keywords - Globalisation, English Language, ICT, Lingua Franca, Internet 


\section{Introduction}

Globalization initially emerged as the term dedicated to the discipline of economics. It referred to the process of connecting different economies to initiate trade and commerce, but today it has not left any aspect of human life untouched be it language, culture, polity, media, entertainment, education or lifestyle. Globalization which has become a fashionable catchphrase and is often tossed across these days, was rarely used before the 1980s. Theodore Levitt is credited to popularise the term globalisation through his article entitled "Globalisation of Markets" published in the Harvard Business Review in 1983. During that time, the international brands and MNCs to name a few such as Coca- Cola, McDonalds and Revlon were taking their products to countries around the world. To define such a process of interconnecting the world's market whereby people around the world can buy international products at their disposal, Levitt used the term globalisation (Sinha, 2006). However, globalisation does not merely give access to buy international brands rather it also provides an opportunity to bring local and indigenous products to global setup because national and international are relative terms, what is local or national for people of one part of the world is international for people of other parts of the world. Perhaps, this characteristic of globalisation of providing the opportunity to enjoy international and promote national or domestic products on a single platform is one of the most important reasons for the sudden proliferation of the globalisation process. However, it is also imperative to mention that the process of globalisation of interconnecting the world would not have been a success as it is today without information and communication technology which is the backbone of globalisation along with the English language which serves as a lingua franca (Graddol, 2006). 
English as the Lingua franca

In the past two decades, globalization has brought about a revolution in the world. In the process of globalisation, language plays a significant role. Language is the primary medium of interaction, and no social, economic or political relations can be built in the absence of language. However, there are thousands of languages spoken around the world. So, the next problem was to choose one language as the lingua franca (common code) which could make communication possible between people around the world (Sinha, 2006). The only language that could serve as the common code was English. English has taken the status of lingua franca not because it is the most used language, (Mandarin Chinese has more speakers than English) but because it is used by more non-native speakers than native speakers. It is the most popular second language by choice. It is the language that people of different language groups and cultures use (Graddol, 2006). According to Fishman (1977), an important characteristic for a language to be identified as lingua franca is that it should not be identified as the language of a particular ethnic group or community (Sinha, 2006:23). This is one important reason why non-Hindi speaking Indians, especially South Indians, prefer speaking English to Hindi because they believe Hindi as the language spoken by a particular ethnic group. Hence, English is the language used as a tool for communication rather than a source of identity. It is the language which makes intercultural communication possible and hence, is at the heart of an interconnected world.

Graddol (2006) opines that the global spread of English as a lingua franca does not seem to be in the interest of the native speakers of English instead it is in a way putting challenges on the native speakers. English is no longer considered as the language of its native speakers. Thus, an important change that has been witnessed recently is that English is not only the language of the UK and the US; rather, it is the language of all those who are using it. 
The gigantic dissemination of English worldwide has also given rise to different new localized and indigenized varieties of English spoken throughout the world. With the increasing use of English by people of different linguistic and cultural background, localised versions of English are appearing. Localised versions of English are taking birth from English coming in contact with other languages and hence, they differ from British and American English at the levels of phonology, vocabulary, syntax and usage. Gargesh (2006) identifies some of the features of English spoken in India. They are as follows:

For example, at the level of phonology, Indian speakers often use monophthongs /e/ in place of diphthongs /ei/ as in words like cake, play, may etc.

Vocabulary: Using words like finger chips for French fries.

Syntax: Indians generally do not invert the auxiliary verbs while forming questions. For example: When you are coming from Delhi? What you would like to have at dinner? They also popularly use isn't it or no as question tags, e.g., You are coming to the party, no? It was raining in the morning, isn 't it?

Usage: Indians often repeat words and say very very to put extra emphasis similar to the way it is used in Indian languages. There are also certain ways that do not sound polite when used in a certain context. For example we often say "please enlighten me" instead of "please let me know" when we want to know something. A request in American English when offering something will be as Won't you have more? sounds impolite for Indians. Indians would rather say "just this much, have some more" (cited from Shin, 2013).

To capture the increasing use and different varieties of English in different contexts, BrajKachru (1985) gave three circle model. 
Kachru's Three Circles Model

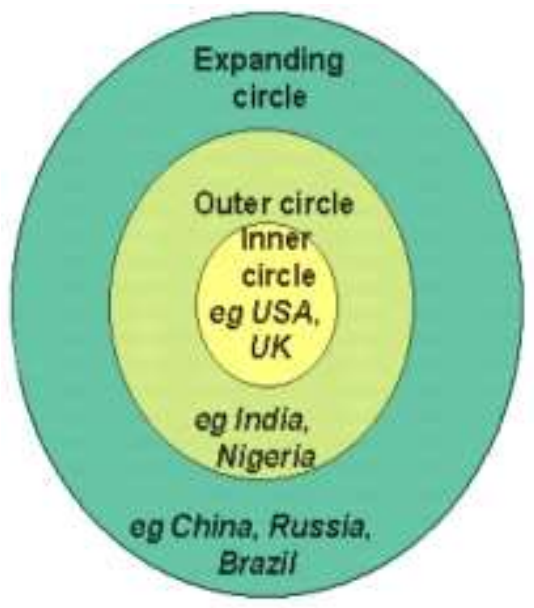

https://en.wikipedia.org/wiki/World_Englishes

The model of Kachru (1985) depicts the three distinct groups of English users around the world:

- INNER CIRCLE (ENL): Countries where English functions as a native language or mother tongue (L1) such as Britain, the USA.

- OUTER CIRCLE (ESL): Countries where English is used as a second language (L2) such as India, Singapore, Nigeria.

- EXPANDING CIRCLE (EFL): Countries where English is studied as a foreign language such as China, Thailand, Brazil.

However, with the introduction of the concept of Global English, the earlier distinction between English as native language ENL, English as second language ESL and English as foreign language EFL has blurred because this model is unable to capture the increasing importance of the outer circle and the degree to which (EFL) users who are supposed to use English as foreign language, e.g., China are becoming more like second language users. Hence, to recognise how English is used in a globalised world, we need to distinguish between proficiencies in English instead of the speaker's bilingual status. Kachru, hence, proposed that the inner circle which was used to represent native speakers is now 
better conceived as one which represents highly proficient or native-like proficient speakers of English regardless of how they learned or use the language (Graddol, 2006).

Another important change that has become prevalent is that the skills of English language proficiency are no longer required only by people who are willing to work, study or live in English speaking countries. Acquiring English proficiency has become a basic skill to operate successfully in today's world regardless of the fact that whether one ever gets into interaction with a native speaker of English or visits an English country in their whole life. Hence, the earlier notion of achieving native speakers like pronunciation and accent and replicating the native speakers model is no longer a necessity. English instructors have also become liberal to accept differences in pronunciation and accent due to the different sociocultural and linguistic background of the learners. Therefore, the focus has shifted from imitating native-like pronunciation to enhancing intelligibility in the communication (Graddol, 2006).

Sinha (2006) writes that the importance that a language enjoys also depends on how powerful are the native speakers of that language. For example, during the heydays of the Soviet Union, the Russian language was gaining much importance. The present status that English is enjoying today is to an extent is an outcome of its expansion and spread, starting with the outreach programme of the Christian Missionaries and the process of Colonization. The terms like McDonaldization of the world or Americanisation are sufficient enough to depict the dominance of American popular culture, cuisines and their imperialism on the entire world. However, the status that English is enjoying today is scarcely because of the strength and wealth of its native speakers but more because of the increasing number of its second language users. Graddol (2006), based on the data provided by Ethnologue, cites the ranking of languages based on second language users, wherein English is the second largest language in terms of second language users after Mandarin. Graddol further says that the 
number of second language users of English is far greater than what is mentioned in Ethnologue and may be now it would be approaching the figure shown for Mandarin (Ostler, 2005 cited by Graddol, 2006).

Another important change that has been identified in the role of English is that no single language will hold the monopolistic position in the $21^{\text {st }}$ century. English is the preferred language for international communication and in the field of information and technology because most of the researches in these fields are done in the USA though often in collaboration with the Japanese or Chinese transnational companies but in English. The research findings are reported in English; most websites, computer systems and software are also in English. Hence, English will remain an important language which is an asset to prosperity for Britain, but it will also bring new pressure and challenges to the overall world's society including Britain because English is not the only show in town rather languages like Chinese, Spanish are ready to compete English. However, this does not mean that the future of English as a lingua franca is bleak. English will be required as a basic skill, but people all over the world, including British need to become bilingual or trilingual to successfully function in the globalised world (Graddol, 2006).

Future of English language

Undoubtedly, English is the language which rules over the computers and the internet but the earlier notion that if one wants to use computers and the internet, then he/she must know English is no longer true. Thus, the lack of English is no longer a barrier for people who wish to use these language technologies. Graddol (2006) writes that the number of internet users with English as their first language and the proportion of English material available on the internet are declining. In November 2005, Byte Level Research analysis examined various studies and concluded that the next internet revolution would not be in 
English. However, the most important thing to note here is that the proliferation of other languages on the internet has merely affected the role English plays in global reach. English still holds the key when communication between people with different mother tongue has to take place. Out of ten languages that are used in internet communication, English is still the number one language on the internet in terms of users followed by Chinese (Shin, 2013).

In a globalised world, it is highly important for citizens, corporations and businesses to be aware of the world's scenario and developments which could affect their lives and decision-making. To make people aware of what is happening around the world, international news plays a crucial role. The international news trend has long been dominated by English channels such as Associated Press, Reuters, the BBC or CNN. However, the last decade of the $20^{\text {th }}$ century has witnessed the emergence of rival channels in other world languages. In 1996, the first international news channel named Al Jazeera, which is based in Qatar started as an independent source of news about events in the Middle East and that in Arabic. With the emergence of $\mathrm{Al}$ Jazeera, the Arabic language suddenly gained importance in international news affairs. Other channels like Al Arabiya in 2003 from Dubai and Al Hurra in 2004 from the US Washington studios started transmitting news in Arabic to different Arab countries. This trend led to the emergence of more channels not only in Arabic but also in other languages of the world. For instance, Latin America started its Spanish channel on $31^{\text {st }}$ October 2005.

However, the emergence of channels in languages other than English has failed to affect the status of English in the transmission of the world's news. English remains the preferred language for news presentation as no language other than English makes sure global reach. Realising the importance of English, even Al Jazeera announced to go global in English and by the end of 2005; its English website became a major source of news for the American internet users. And in November 2006, it also launched its new English Channel 
under the name "Al Jazeera English". Thus, other languages like Spanish, Arabic and French are being adopted by news media but no language can replace or even affect the status of English. English is still used widely as a language of international reach.

Graddol (2006) remarks that "English is regarded as a gateway to wealth for national economies, organisations and individuals. If this is correct then the distribution of poverty in future will be closely linked to the distribution of English". India and other such countries which were once under the rule of British colonialism have received English as a legacy. In the old modernist society, English proficiency was used as a marker for a select, educated, middle-class group of people. This idea is prevalent even today in the second decade of the $21^{\text {st }}$ century. English in India symbolizes quality education, posh culture, and rich intellect. This makes clear the fact that English is associated with educated people and a better lifestyle. English has both communicative and educative value, which makes it the world's most widely used language. English in this globalised world is playing an extremely important role in providing access to global knowledge and jobs in which English serves as the only common language to make communication take place between customers and colleagues. Business deals and negotiation are impossible without English. However, this is raising another potent problem that English despite playing an extremely important role in today's world has become the key mechanism for bringing inequality in developing countries. Unavailability or lack of English proficiency among people of some developing countries threatens them that they could be excluded as a minority because the majority of the world knows English. In other words, lack of English creates fear and isolation. Isolation from the entire world and fear of lagging behind which may affect their personal, social, educational and professional growth. It is because, for most of the workers migrating to another country in search for a better job and livelihood, English has become a necessary skill. For example, 
Malaysia in 2003 announced that basic proficiency in English is mandatory for all foreign employees (Graddol, 2006).

Language on the internet

Discussion of effects of globalisation on language cannot be completed without discussing how internet which is a gift of the global age is shaping language and languages. Terms like netspeak, weblish, netlish, cyberspeak, electronic discourse, electronic language, interactive written discourse and computer-mediated communication have emerged to describe the characteristics of language used on the internet. Linguists and writers have called the language of the internet as "written speech" because it is written in the way language is spoken (Crystal, 2004). However, the question that has been posed is to what extent we can write speaking.

Along with words paralinguistic aspects like body action which includes gestures, facial expressions, hand movements, eye contact, head movement etc and voice, tone and intonation contribute a lot in understanding the intentions and mood of the speaker in face to face conversation which is absent in netspeak. Speech is often marked by the necessity of feedback from the receivers through their expressions. Hence, the question that arises when the electronic discourse is termed as written speech that, is it possible to bring these features of speech into writing? Crystal (2004) has created a list of characteristics of spoken and written communication and then has compared it with the language used in different internet communities such as web, chat groups and emails. It is found that netspeak share characteristics of both speech and writing. Although some internet communities share more similarities with speech while others share more with writing, some, writings on web pages are however more structured, planned, factually rich, follow the writing conventions, rules of grammar and a proper format. These writings are very much similar to ones found in research 
articles, or letters, stories, reports etc. Like traditional writing, they are constantly revised, structurally complex and also get delayed feedback.

E-mails, chat groups, virtual worlds, on the other hand, show more features of speech than writing although they are also written. They are mostly time-bound and expect time bound or instant response instead of feedback as they can be deleted or lost to attention as newer messages or emails appear. The language used also shows urgency and force similar to face to face conversations. Now if we compare between only email and chatgroup conversations then that it is likely that chatgroups conversations are inclined more towards speech norms because in chatgroups we chat as we chat in face to face conversations, the language used is also usually casual or informal, loosely structured and requires instant feedback or else the feel of conversation gets lost.

To conclude, the language used in electronic discourse is an eclectic resource which shares the features of both writing and speech based on the communicative needs of the users (Davis and Brewer, 1997:19, cited from Crystal, 2004). According to Crystal (2004) so, netspeak should be considered a new species of communication sharing the properties of speech, writing and electronically mediated properties which make it a new and third medium of communication as independent as the other mediums namely speech and writing.

Influence of Information and Communication Technology on the English Language

In the past two decades, globalization has brought about a revolution in the world. It seems as if the older ways of communication, such as the concept of letter writing or telegram has vanished from the world. The advent of new technology has enabled us to send text messages, Short Message Services (SMS), Multimedia Message Services (MMS), engage in video or audio calling with people living on any side of the earth within seconds. People spend a lot of time chatting and calling via different social sites. The widespread and frequent use of these sites has an impact on the way we use language. This technology- 
mediated communication has not only popularised the use of the English language but has also changed English a lot. The widespread use of technology, easy availability of high-speed internet, cell phones, laptops, tablets etc. has given rise to a new medium of communication which includes the characteristics of speech, writing and electronically mediated communication. This new medium of conversation has impacted the ways of using the English language, especially the way English was written. The use of slangs, acronyms, emoticons have made communication condensed, instant, and exciting, but these ideas being implemented in our writing has changed the very heart and soul of the English language. And as a result of constant exposure to language technologies, people have become so used to electronic discourse that features of netspeak is constantly being found in our writing. The features of netspeak when found in writing in academic and formal context poses an important issue and as a consequence, academicians and teachers often share their concern and worry that excessive use of netspeak is affecting both mediums of communication namely speech and writing but especially writing. However, Crystal claims that in L1 teaching, there is no evidence at all of the students inserting textism in academic writing. $\mathrm{He}$ further adds that he had a discussion with students on media myth that they use abbreviations, slangs in academic work, but he found the students, totally dismissive. However, as far as L2 context is concerned, the researcher has often found traces of textism in academic works in form of abbreviations, short forms, contractions, and informal vocabulary and sentence structures.

\section{Conclusion}

The advent of globalisation has led to the worldwide dissemination of English. It has changed its role from a foreign language to lingua franca and has given rise to different varieties of English. Moreover, it has made English, the most used language in the internet 
communication. The increasing use of internet has altered the way people communicate and most importantly has given birth to a new medium of communication in addition to speech and writing where English serves as a tool for communication in this third medium. Different linguists have different opinion about this third medium of communication. Language experts, academician and authors like John Sutherland and John Humphrys think that internet-mediated communication system has not only changed but has also deteriorated English. John Sutherland (2008) says "Texting is the penmanship for illiterates." (https://www.theguardian.com/books/2008/jul/05/saturdayreviewsfeatres.guardianreview)

On the contrary, noted linguist Crystal, thinks that it improves children's writing and vocabulary. Another eminent linguist John McWhorter shares a similar opinion with Crystal and argues that it has given rise to a more natural way of communication. It is devoid of the formal notions of writing that it is planned, structured, and follows the rules of grammar much more strictly as compared to speech. It has filled the gap that used to exist between written and spoken norms of language.

The researcher believes that each coin has two faces, so has the effects of globalization on the English language. The researcher thinks that it is wrong to say that globalization has changed the English language forever; rather, we have changed the English language for our own sake and comfort in the light of globalization. However, the worry of language teachers, academicians and linguists who think that the use of netspeak is deteriorating the way English was used in writing should also be considered. A midway should be adopted by language instructors where students should be trained to know when to switch over from this new species of communication to traditional mediums of communication. Especially in academic settings learners should be asked to avoid using short forms, slangs, colloquial words and phrases when speaking or writing. 


\section{Acknowledgements}

I would like to owe my gratitude to the exemplary linguist David Crystal for responding to my emails and answering my queries. I am incredibly thankful for his kindness. Another important person who needs to be acknowledged is my supervisor Prof. Kausar Husain for reading this paper and enlightening me with her knowledge. Thank you so much for your unwavering support. 


\section{References}

Crystal, D., (2004). Language and the Internet. Cambridge, United Kingdom: Cambridge University Press.

Graddol, D. (2006). English Next. Oxford, United Kingdom: OxfordUniversity Press.

Kachru, Braj B. "Standards, codification and sociolinguistic realism: the English language in the outer circle. In R. Quirk and H. Widdowson (Eds.). English in the World: Teaching and Learning in the Language and Literatures: Cambridge University Press, 1985.

Shin. S. J., (2013) Bilingualism in Schools and Society: Language, Identity, and Policy. NY \& UK, Routledge.

Sinha, A. K. (2006). Globalization: The Linguistic Perspective. In B.N. Patnaik \& S.I. Hasnain (Ed.), Globalization: Language, Culture and Media (pp. 17- 27). New Delhi, India: Indian Institute of Advanced Study, Shimla.

$2 b$ or not $2 b$ ? Retrieved on $25^{\text {th }}$ September; 2016 from www.theguardian.com/books/2008/jul/05/saturdayreviewsfeatres.guardianreview

World Englishes $\quad$ Retrieved on $31^{\text {st }}$ October; 2019 from en.wikipedia.org/wiki/World_Englishes 